\title{
TESIS
}

\section{PREVALENCIA DEL SÍNDROME DE BURNOUT EN MÉDICOS GINECOOBSTETRAS QUE LABORAN EN LOS HOSPITALES NACIONALES EDGARDO REBAGLIATI MARTINS Y GUILLERMO ALMENARA IRIGOYEN DE AGOSTO DEL 2007 A ENERO DEL 2008*}

\author{
Albengrin Mendoza, Edson Raúl ${ }^{1}$ y Galvez Valverde, Alberto Anibal ${ }^{2}$ \\ Facultad de Medicina Humana de la Universidad Nacional del Centro del Perú
}

\begin{abstract}
RESUMEN
Se define como Síndrome de Burnout a la respuesta frente al estrés laboral crónico que sufren los profesionales que trabajan en contacto directo con otras personas. Los médicos ginecoobstetras son vulnerables al desarrollo del síndrome de Burn0ut, por realizar jornadas de trabajo muy sacrificados, encontrarse bajo la presión de velar por la vida de dos seres humanos y además ser esta especialidad susceptible de problemas médico legales. Objetivos: Determinar la prevalencia del Síndrome de Burnout y describir la posible relación con algunos factores sociodemográficos. Materiales y Métodos: El presente es un estudio de tipo descriptivo, prospectivo de corte transversal, mediante el cuestionario "Maslach Burnout Inventory" y una encuesta sobre factores sociodemográficos en una población de estudio de 60 médicos, de los Hospitales Nacionales Edgardo Rebagliati Martins y Guillermo Almenara Irigoyen Resultados: 60 médicos, el 2 \% de la población de estudio resulto positivo al síndrome de BurnOut, el 93\% se encuentra en riesgo de padecer síndrome de BurnOut y el $5 \%$ restante no presento ningún grado de BurnOut; de las variables sociodemográficas, mas de 6 horas de trabajo directo con pacientes, pocas horas de esparcimiento, menos de 20 años de servicio y condición laboral "contratado", resultaron como factores resaltantes dentro de los casos positivos y los de riesgo. Conclusiones: Del presente trabajo, se destaca que a pesar de tener solo un caso positivo casi la totalidad de la población con un porcentaje de 95\% esta en riesgo de padecer Burn0ut, y para ello es importante implantar medidas de prevención. Además se denota la necesidad de ampliar el estudio a los médicos de nuestra región.
\end{abstract}

Palabras Clave: Síndrome de BurnOut, Inventario Maslach, estrés laboral.

\footnotetext{
* Esta tesis fue recibida para su revisión el 26/10/2009 y aprobado para su publicación 16/11/2009

${ }^{1}$ Egresado dela Facultad de Medicina Humana

${ }^{2}$ Egresado dela Facultad de Medicina Humana
} 


\title{
PREVALENCE OF BURNOUT SYNDROME IN MEDICAL GYNECOLOGIST WORKING IN THE EDGARDO REBA- GLIATI MARTINS NATIONAL HOSPITALS AND GUILLERMO ALMENARA AUGUST 2007 TO JANUARY 2008
}

\begin{abstract}
It is defined as A Burnout's Syndrome to the response opposite to the chronic job stress that $t$ suffer the professionals who work at direct contact with other persons. The doctors obstetrics and gynecologists are vulnerable to the development of BurnOut syndrome, for realizing days of work very sacrificed, to be under the pressure of guarding over the life of two human beings and in addition to be this speciality capable of legal doctor problems. Objective: To determine the prevalencia of Burnout Syndrome and to describe the possible relation with some factors sociodemográficos. Materials and Methods: The present is a study of descriptive, market type of transverse court (cut), by means of the questionnaire "Maslach Burnout Inventory " and a survey on factors sociodemographic in a population of study of 60 doctors, of the National Hospitals Edgardo Rebagliati Martins and Guillermo Almenara Irigoyen. Results: About 93\% of study population, that is 56 subjects of study, are in risk to have BurnOut syndrome, $5 \%$ that is 3 subjects of study don't present BurnOut syndrome, and the last $2 \%$ that is 1 subject has BurnOut syndrome. In sociodemographic variables, more than 6 hours of direct work with patients, few free hours, less of twenty years of work in hospital, and to be a Contracted worker, are the ones related to BurnOut syndrome. Conclusions: Of the present work, one emphasizes that in spite of a positive case has alone, almost the totality of the population who makes a percentage of $95 \%$ is in risk of suffering BurnOut, so it is important to implement prevention measures, besides it is possible to prevent the installation of the syndrome.
\end{abstract}

Key words: BurnOut Syndrome, Maslach BurnOut Inventory, Work Stress. 